\title{
Mast Cell Activation and Migration to Lymph Nodes during Induction of an Immune Response in Mice
}

\author{
Hong-Wei Wang, Nicodemus Tedla, Andrew R. Lloyd, Denis Wakefield, and H. Patrick McNeil \\ Inflammation Research Unit, School of Pathology, University of New South Wales, Sydney, 2052 Australia
}

\begin{abstract}
The mast cell response in skin and lymph nodes was examined during the sensitization phase of dinitrofluorobenzene (DNFB)-induced contact hypersensitivity in mice. Degranulation of $62 \%$ of mast cells in DNFB-exposed skin was evident within $30 \mathrm{~min}$ of a dual application of DNFB, reaching a peak of $77 \%$ at $24 \mathrm{~h}$, and persisting in $42 \%$ after $5 \mathrm{~d}$. Abundant expression of macrophage inflammatory protein (MIP)-1 $\alpha$ and MIP-1 $\beta$ mRNAs and proteins was observed in keratinocytes, and mast cell degranulation was significantly inhibited after administration of neutralizing antibodies to MIP-1 $\alpha$, but not MIP-1 $\beta$. During DNFB sensitization, the mast cell density in the skin decreased by half, concurrent with a fivefold expansion of mast cell numbers in draining lymph nodes. Fluorescent-labeled mast cells injected into the skin appeared in draining lymph nodes after application of DNFB, followed by subsequent migration to the spleen. In lymph nodes, mast cells were an abundant and predominant source of MIP-1 $\beta$, neutralization of which partially inhibited $\mathrm{T}$ lymphocyte recruitment. These results indicate that mast cells contribute to the induction of this primary immune response by activation at and migration from the site of antigen encounter to draining lymph nodes, wherein they mediate $\mathrm{T}$ lymphocyte recruitment by production of MIP-1ß. (J. Clin. Invest. 1998. 102:1617-1626.) Key words: dinitrofluorobenzene - MIP-1 $\alpha$ - MIP-1 $\beta$ - cell migration $\bullet$ contact sensitivity
\end{abstract}

\section{Introduction}

A role for mast cells in a range of inflammatory and immunological events has been established clearly (1). For example, mast cells or their products have been shown to be pivotal in mediating leukocyte recruitment in vivo (2-5), they appear to play a key role in defense against bacterial infections (6-8), they interact directly with cells of the adaptive immune system (9-11), they are a primary source of a range of cytokines (5, 12-16), and they can present exogenous antigen to T lymphocytes in vitro (17-19).

Apart from classical IgE-mediated mechanisms, mast cells can be activated by cross-linking of surface FcyRIII molecules

Address correspondence to Dr. H. Patrick McNeil, Inflammation Research Unit, School of Pathology, The University of New South Wales, Sydney, NSW 2052, Australia. Phone: 61-2-9382-2653; FAX: 61-2-9382-2787; E-mail: P.McNeil@unsw.edu.au

Received for publication 13 April 1998 and accepted in revised form 1 September 1998.

J. Clin. Invest.

(C) The American Society for Clinical Investigation, Inc. 0021-9738/98/10/1617/10 \$2.00

Volume 102, Number 8, October 1998, 1617-1626

http://www.jci.org
$(20,21)$, augmented by immune complex-mediated complement fixation $(22,23)$. A range of small peptides has been reported to elicit mast cell degranulation including substance $\mathrm{P}$ (24), calcitonin gene-related peptide (25), and endothelins (26). The $\beta$-chemokines, monocyte chemoattractant peptide $(\mathrm{MCP})^{1}-1$ and macrophage inflammatory protein (MIP)- $1 \alpha$, cause degranulation of mouse or rat mast cells in vitro $(27,28)$ and in vivo (29), although others have reported that these and other $\beta$-chemokines cause migration, but not activation of mast cells in vitro (30).

Increases in the local density of mast cells within inflamed tissue have been described in a number of diseases such as asthma (31) and rheumatoid arthritis (32). Such increases could occur by recruitment of mast cell precursors from the circulation followed by local maturation, local proliferation of resident mast cells, or migration of mature mast cells from adjacent tissues. The latter possibility is supported by reports that mast cell numbers increase in airway mucosa of dogs within $1 \mathrm{~h}$ of local antigenic challenge (33), and that there is a significant increase in submucosal mast cell density in human asthmatic lungs $6 \mathrm{~h}$ after antigen exposure (34). The kinetics of cell accumulation observed in these studies support rapid migration of mature mast cells, and recently Friend et al. provided evidence of mast cell migration from the jejunum to the spleen during resolution of intestinal parasitic infection in mice (35).

In this study, we have examined in detail the mast cell response in the skin and draining lymph nodes of mice during the sensitization phase of dinitrofluorobenzene (DNFB)-induced cutaneous contact sensitivity. Induction of this primary immune response provides a model to study the interaction of mast cells with cells involved in adaptive immunity in vivo. We have found that mast cells exhibit prominent and prolonged degranulation in the skin, which is partially due to local production of the chemokine MIP-1 $\alpha$. Furthermore, we have found that skin mast cells migrate in large numbers to the draining lymph nodes, wherein the primary immune response is initiated. In lymph nodes, mast cells are the primary source of a second chemokine, MIP- $1 \beta$, which acts to recruit T lymphocytes to the lymph node. This is the first direct evidence in vivo that mast cells migrate from a site of antigen encounter, via afferent lymphatics to the draining lymph nodes, wherein they participate in induction of a primary immune response.

\section{Methods}

Sensitization with DNFB. $\mathrm{C} 3 \mathrm{H} / \mathrm{HeN}$ and BALB/c sex-matched mice, at $6-8$ wk of age, were obtained from the Animal Breeding and Holding Unit, the University of New South Wales, and kept under specific pathogen-free conditions throughout the experiment. $25 \mu \mathrm{l}(1.5 \mu \mathrm{g})$

1. Abbreviations used in this paper: AEC, 3-amino-9-ethylcarbazole; $\mathrm{BMMC}$, bone marrow-derived mast cell; DNFB, dinitrofluorobenzene; MCP, monocyte chemoattractant peptide; MIP, macrophage inflammatory protein; $\mathrm{mMCP}-5$, mouse mast cell protease-5. 
of $0.5 \%$ DNFB in 4:1 acetone/olive oil (Sigma Chemical Pty. Ltd., Sydney, Australia) was applied onto the shaved abdomen or footpads of mice on days 0 and 1 , according to the previously described optimal dosage for these mouse strains (36). Control animals were painted with acetone/olive oil (vehicle control). In some experiments, $\mathrm{BALB} / \mathrm{c}$ mice were treated with an intraperitoneal injection of 50 or $500 \mu \mathrm{g}$ per animal of goat anti-mouse polyclonal neutralizing antibodies directed against MIP- $1 \alpha$ or MIP- $\beta$ (R\&D Systems, Minneapolis, MN), $4 \mathrm{~h}$ before DNFB sensitization. Control animals were injected with the same amount of pooled normal goat IgG.

Histological studies. The animals were killed at various time points of the experiment. Skin and lymph node specimens were fixed in Carnoy's solution or $10 \%$ buffered formalin ( $\mathrm{pH} 7.0$ ), respectively, and embedded in paraffin. $4-\mu \mathrm{m}$ serial sections were cut. Mast cells were stained with the previously described $0.5 \mathrm{~N} \mathrm{HCl}(\mathrm{pH} 0.5)$ toluidine blue method (37).

Quantitative histomorphometric assessment of mast cell density in toluidine blue-stained sections was performed using a computerassisted image analysis system (38). The slides were coded before counting and analyzed by a microscopist unaware of the treatment allocation. The mast cell density was calculated as cell number per $\mathrm{mm}^{2}$ of section area. Mast cell degranulation was graded according to a previously published method (39). Percent degranulation was calculated as: (degranulated mast cell count/total mast cell count $) \times 100$.

Immunohistochemical staining. An antigen retrieval procedure was undertaken by heating paraffin sections in a microwave oven in $0.01 \mathrm{M}$ citrate buffer ( $\mathrm{pH}$ 6.0). Endogenous peroxidase activity was inhibited in $3 \% \mathrm{H}_{2} \mathrm{O}_{2}$ for $10 \mathrm{~min}$. Sections were then incubated with primary antibodies; goat anti-mouse MIP- $1 \alpha$ or MIP-1 $\beta$ (R\&D Systems), and affinity-purified polyclonal rabbit anti-mouse mast cell protease-5 (mMCP-5) (40), for $1 \mathrm{~h}$ at room temperature, followed by HRP-conjugated donkey anti-goat IgG (Serotec, Australian Laboratory Services, Sydney, Australia) for $1 \mathrm{~h}$; or biotinylated goat antirabbit antibody (DAKO, Glostrup, Denmark) for $40 \mathrm{~min}$, followed by streptavidin-HRP (Vector Laboratories Inc., Burlingame, CA) for 1 h. 3-amino-9-ethylcarbazole (AEC) was used as a chromogen followed by counterstaining with hematoxylin.

In situ hybridization. A nonisotopic in situ hybridization technique was used to investigate MIP- $1 \beta$ and MIP- $1 \alpha$ mRNA expression. Single-strand cRNA probes were produced from murine MIP$1 \beta$ and MIP- $1 \alpha$ plasmid cDNAs by in vitro transcription and labeled by the digoxigenin method (Boehringer Mannheim, Berlin, Germany). Paraffin sections were treated with $0.2 \mathrm{~N} \mathrm{HCl}$ for $15 \mathrm{~min}$, digested with proteinase $\mathrm{K}(10 \mu \mathrm{g} / \mathrm{ml})$ for $30 \mathrm{~min}$ at $37^{\circ} \mathrm{C}$, fixed in $4 \%$ paraformaldehyde for $5 \mathrm{~min}$, and rinsed with PBS. After a 2-h prehybridization at $48^{\circ} \mathrm{C}$, slides were hybridized with the cRNA probes $(100 \mathrm{ng} / 25 \mu \mathrm{l})$ at $48^{\circ} \mathrm{C}$ overnight, after which the slides were washed twice with $2 \times$ SSC for $15 \mathrm{~min}$. Unhybridized probe was digested in $100 \mu \mathrm{g} / \mathrm{ml} \mathrm{RNase}$ at $37^{\circ} \mathrm{C}$ for $30 \mathrm{~min}$. The slides were then washed in $2 \times$ SSC and $1 \times$ SSC for $15 \mathrm{~min}$ each, followed by another $15-\mathrm{min}$ wash with prewarmed $0.5 \times \mathrm{SSC}$ at $48^{\circ} \mathrm{C}$. Sections were processed for immunological detection as described in the DIG nucleic acid detection protocol (Boehringer Mannheim), then counterstained with 1\% neutral red and mounted.

Generation of fluorescent-labeled bone marrow-derived mast cells $(B M M C)$. BMMC were obtained by culturing primary bone marrow cells from BALB/c mice as described previously (40) with the following modifications. Bone marrow cells were cultured in complete Iscove's modified Dulbecco's media (GIBCO BRL, Gaithersburg, MD) supplemented with a combination of $30 \%$ WEHI-3B cell conditioned media and $20 \%$ NIH 3 T3 cell conditioned media. The purity of 6 -wk cultured BMMC was $>95 \%$ by toluidine blue staining. The PKH fluorescent general cell linker kit was purchased from Sigma, and the labeling procedure was undertaken according to the kit protocol. The efficiency of labeling determined by flow cytometry was 99.1 and $96.5 \%$ with $\mathrm{PKH} 26$ and $\mathrm{PKH} 2$, respectively (data not shown). After PKH labeling, viability of BMMC cells was $94 \%$ by trypan blue exclusion. The left footpad of each BALB/c mouse was intradermally injected with $10^{6}$ PKH26 (red fluorescent) labeled BMMC, and the right footpad with $10^{6} \mathrm{PKH} 2$ (green fluorescent) labeled cells. After $48 \mathrm{~h}$ the left footpad was painted with $10 \mu \mathrm{l}$ of $0.5 \%$ DNFB in 4:1 acetone/olive oil on days 0 and 1, and the right footpad was painted with acetone/olive oil as control. The animals were killed at 4 and $24 \mathrm{~h}$ after the second DNFB application. There were four mice in each time point. Footpads and popliteal lymph nodes were collected and frozen sections were cut. The sections were examined under a fluorescent microscope.

Statistical analysis. A two-tailed Mann-Whitney test was performed with the statistical software program, SPSS for Windows Rel 7.0 (SPSS Inc., Chicago, IL). Data were expressed as mean \pm SEM. $P<0.05$ was considered significant.

\section{Results}

MIP-1 $\alpha$ and MIP-1 $\beta$ expression is induced in skin after DNFB sensitization. In the skin of acetone/olive oil-treated control mice, basal expression of the MIP- $1 \alpha$ gene was detected by in situ hybridization in the cells surrounding hair follicles (data not shown). This was further confirmed by immunohistochemical staining showing MIP- $1 \alpha$ protein to be present in these cells (Fig. $1 A$ ). Although keratinocytes did not express this chemokine in control mice, a single application of DNFB caused a rapid appearance of MIP- $1 \alpha$ mRNA at $30 \mathrm{~min}$ and protein at $2 \mathrm{~h}$ in the keratinocytes of the exposed skin, and there was substantially enhanced staining for MIP- $1 \alpha$ protein around hair follicles. Abundant MIP- $1 \alpha$ protein was present in keratinocytes by $8 \mathrm{~h}$ after a single DNFB exposure (Fig. $1 B$ ), and remained as long as $48 \mathrm{~h}$ after the second DNFB exposure (data not shown).

In contrast to MIP- $1 \alpha$, there was no basal expression of either MIP-1 $\beta$ mRNA or protein in control skin (data not shown). However, as early as $4 \mathrm{~h}$ after a single exposure to DNFB, MIP-1 $\beta$ mRNA expression was clearly evident in keratinocytes, mainly at the basal layer of the dermis and in hair follicles (Fig $1 C$ ). Whereas MIP-1 $\alpha$ protein was detected as early as $2 \mathrm{~h}$ after a single DNFB exposure and was abundant at the 8 -h time point (Fig. $1 \mathrm{~B}$ ), the appearance of MIP-1 $\beta$ protein was slower, being detectable by $8 \mathrm{~h}$, and abundant at $24 \mathrm{~h}$ after dual DNFB application (Fig. $1 D$ ). Fibroblasts were also found as a source of MIP-1 $\beta$ mRNA after the second DNFB application. Additional cells which contained MIP-1 $\beta$ mRNA were identified as mast cells using immunostaining with antimMCP-5 antibody on adjacent sections of the skin (Fig. 1, E and $F)$.

DNFB sensitization causes a rapid and prolonged activation of skin mast cells. As assessed by toluidine blue staining, there was no evidence of significant mast cell degranulation in sections of control skin at any time point after treatment with the DNFB vehicle, acetone/olive oil (Fig. $2 A$ ). A minority of mast cells appeared activated (grade $1+$ degranulation), after a single exposure to DNFB, with a gradual increase up to $13.9 \pm 0.1 \%$ of skin mast cells showing degranulation at the 8 -h time point. In contrast, there was a profound response after a second exposure to DNFB, which induced $61.7 \pm 3.5 \%$ of all mast cells to degranulate within $30 \mathrm{~min}$, with the degranulation graded up to $3+$ at $4 \mathrm{~h}$ after the second painting (Fig. 2 B). By $24 \mathrm{~h}$, the percentage of mast cells showing degranulation reached a maximum of $76.7 \pm 7.3 \%$, and even at day 5 after the second exposure, $41.3 \pm 6.6 \%$ of mast cells still exhibited degranulation (Fig. 2 E). This persistent mast cell degranulation gradually resolved with a return to control levels by day 28 , al- 

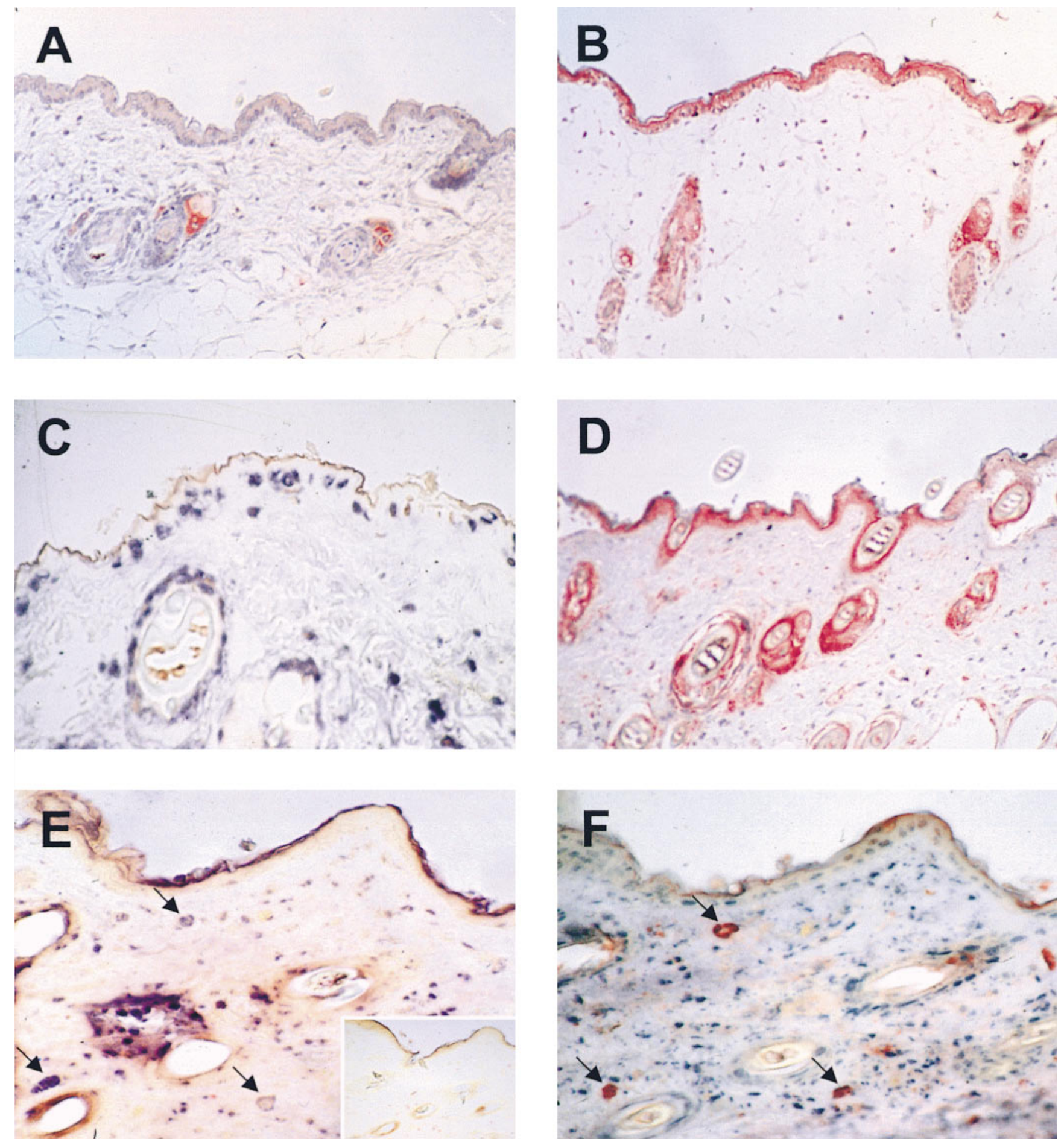

Figure 1. DNFB sensitization induces expression of MIP-1 $\alpha$ and MIP-1 $\beta$ in the skin. Immunohistochemical staining (AEC, red color) for MIP-1 $\alpha$ in control mouse skin $(A)$, showing baseline expression of MIP- $1 \alpha$ protein in the cells surrounding hair follicles, and $(B)$ skin at $8 \mathrm{~h}$ after the first DNFB application, where there is abundant expression of MIP-1 $\alpha$ protein by keratinocytes as well as in cells surrounding hair follicles. (C) In situ hybridization of MIP-1 $\beta$ mRNA (blue staining) in keratinocytes $4 \mathrm{~h}$ after the first DNFB application. $(D)$ Immunohistochemical staining for MIP-1 $\beta$ (AEC, red color) in skin at $24 \mathrm{~h}$ after the second application of DNFB. ( $E$ and $F$ ) Mast cells were identified as a source of MIP-1 $\beta$ mRNA in the skin after DNFB. In situ hybridization of MIP-1 $\beta$ mRNA in numerous cells in the dermis, including three cells indicated with arrows $(E)$. Immunohistochemical staining of the adjacent section $(F)$ with anti-mMCP-5 antibody has identified that these three MIP-1 $\beta-$ positive cells are mast cells. Inset in $E$ shows in situ hybridization with the control sense probe in an adjacent section of skin. 

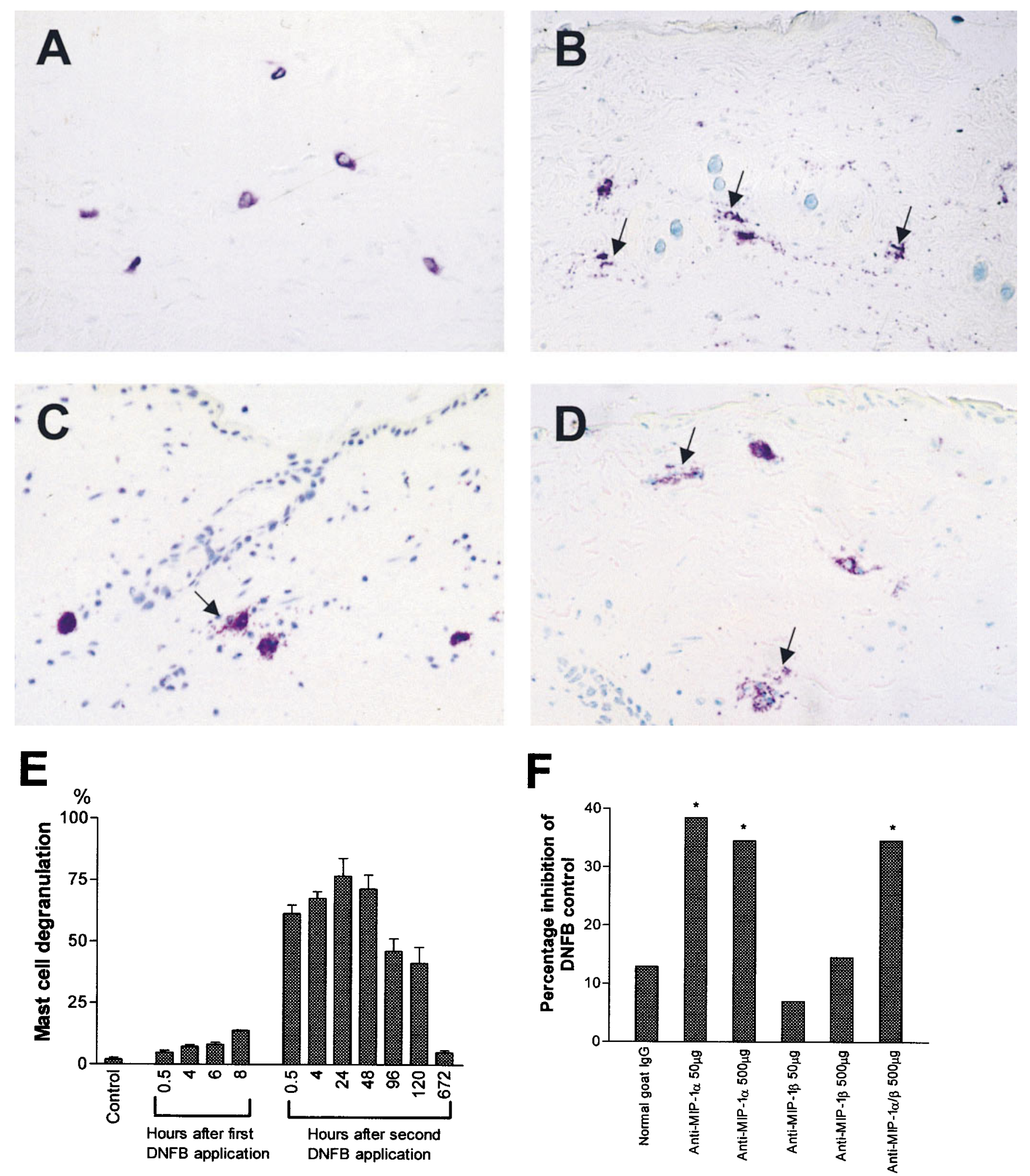

Figure 2. DNFB induces massive and prolonged skin mast cell degranulation which is inhibited by pretreatment with neutralizing anti-MIP-1 $\alpha$ antibody. Toluidine blue staining in abdominal skin taken from mice $4 \mathrm{~h}$ after the second application of acetone/olive oil vehicle alone in control mice $(A)$, showing no degranulation of mast cells, or $(B)$ abundant degranulation of mast cells is apparent after application of DNFB. Toluidine blue-stained granules are evident extracellularly (arrows). In mice pretreated with neutralizing anti-MIP-1 $\alpha$ antibody, there is marked inhibition of degranulation $(C)$, whereas in mice pretreated with neutralizing anti-MIP-1 $\beta$ antibody, there is only mild inhibition of DNFB-induced mast cell degranulation $(D)$. (E) Percentage of mast cells exhibiting degranulation was quantitated on toluidine blue-stained sections at different time points after DNFB painting. Each experimental and control group consist of five animals. The data are expressed as mean \pm SEM. $(F)$ Percent inhibition of mast cell degranulation by anti-MIP- $1 \alpha$ and anti-MIP-1 $\beta$ antibodies. Animals received intraperitoneal administration of either 50 or $500 \mu \mathrm{g}$ anti-MIP- $1 \alpha$ or anti-MIP-1 $\beta$ antibody, a combination of both, or control normal goat IgG, $4 \mathrm{~h}$ before the first DNFB application. The data are expressed as [(mean percentage of degranulation in DNFB group - mean percentage of degranulation in antibody-treated 
though an occasional grade $1+$ degranulated mast cell could be found.

Anti-MIP-1 $\alpha$ antibody inhibits DNFB-induced mast cell degranulation. To determine if the extensive local production of MIP- $1 \alpha$ and/or MIP-1 $\beta$ by keratinocytes after DNFB sensitization was contributing to the prolonged degranulation of mast cells we observed, neutralizing antibodies to MIP- $1 \alpha$ or MIP-1 $\beta$ were administered $4 \mathrm{~h}$ before DNFB sensitization. As assessed by toluidine blue staining $24 \mathrm{~h}$ after the second DNFB sensitization, there was a significant inhibition of mast cell degranulation by anti-MIP-1 $\alpha$ (Fig. $2 C$ ) but not anti-MIP-1 $\beta$ (Fig. $2 D$ ) neutralizing antibodies. Using quantitative histomorphometry on these sections of skin at $24 \mathrm{~h}$ after DNFB sensitization, either 50 or $500 \mu \mathrm{g} /$ animal of anti-MIP- $1 \alpha$ neutralizing antibody caused a mean of $34-38 \%$ inhibition of total mast cell degranulation compared with untreated, DNFB-sensitized animals $(P<0.01)$ or compared with control normal goat IgG-treated, DNFB-sensitized animals $(P<0.05)$ (Fig. 2 $F)$. Inhibition of mast cell degranulation by either 50 or $500 \mu \mathrm{g} /$ animal anti-MIP-1 $\beta$ neutralizing antibodies was not significantly different from the control IgG. The use of a combination of neutralizing antibodies to both MIP- $1 \alpha$ plus MIP- $1 \beta$ resulted in a similar level of inhibition of mast cell degranulation as anti-MIP- $1 \alpha$ antibody alone (Fig. $2 F$ ).

DNFB sensitization causes a reduction of mast cell numbers in skin and an expansion in draining lymph nodes. After a single exposure to DNFB there was a small $(\sim 10 \%)$ reduction in mast cell density in skin (data not shown). After the second exposure to DNFB, statistically significant decreases in mast cell numbers were found in the exposed skin at each time point up to day 5 , in comparison to the numbers in acetone/olive oil-treated control animals $(P<0.05)$ (Fig. $3 A$ ). This reduction in mast cell density in skin gradually returned towards the pretreatment levels by $28 \mathrm{~d}$. On the other hand, there was a rapid and substantial increase of mast cells in the lymph nodes after the two sensitizing exposures to DNFB. From a baseline mean density of $85.3 \pm 4.4$ mast cells $/ \mathrm{mm}^{2}$ of lymph node in acetone/olive oil-treated control mice, a peak mean mast cell density of $198.7 \pm 6.5$ mast cells $/ \mathrm{mm}^{2}$ was observed $4 \mathrm{~h}$ after the second exposure to DNFB (Fig. $3 B)(P<0.01)$. The expansion of mast cells was predominantly in the subcapsular region (Fig. 3 $C$ ), when compared with control lymph nodes (Fig. $3 \mathrm{D}$ ), suggesting possible influx of mast cells via afferent lymphatics.

The draining lymph nodes underwent significant expansion after DNFB sensitization with a 2.5-fold increase in weight and a 3-fold increase in numbers of nucleated cells (Table I). Flow cytometry of lymph node single cell suspensions from DNFBtreated mice showed a fourfold increase in CD3 lymphocytes at $24 \mathrm{~h}$ compared with the numbers in lymph nodes from control-treated mice. Given this overall 2.5-fold increase in lymph node size, the doubling of mast cell density in these enlarged lymph nodes represented an $\sim 5$-fold expansion of total mast cell numbers as assessed at $4 \mathrm{~h}$ after the second DNFB expo-
Table I. Changes in Inguinal Lymph Nodes after DNFB

\begin{tabular}{lccc}
\hline & Weight & $\begin{array}{c}\text { Nucleated cells/ } \\
\text { node }\left(\times 10^{6}\right)\end{array}$ & $\begin{array}{c}\text { T lymphocytes/ } \\
\text { node }\left(\times 10^{6}\right)\end{array}$ \\
\hline & $m g$ & & \\
Control-treated & $15 \pm 0.7$ & $2.3 \pm 0.2$ & $1.1 \pm 0.1$ \\
$\begin{array}{l}\text { DNFB-treated } \\
+ \text { no pretreatment }\end{array}$ & $40 \pm 2.8$ & $7.2 \pm 0.5$ & $4.2 \pm 0.3$ \\
+ normal goat IgG & $37 \pm 1.9$ & $6.4 \pm 0.4$ & $3.5 \pm 0.3^{*}$ \\
+ anti-MIP-1 & $28 \pm 1.8$ & $3.2 \pm 0.1$ & $1.8 \pm 0.1^{*}$ \\
& & &
\end{tabular}

Values are mean \pm SEM $(n=4)$ for lymph nodes taken $24 \mathrm{~h}$ after the second application of acetone/olive oil control or DNFB in animals given no pretreatment or pretreated with $500 \mu \mathrm{g} / \mathrm{animal}$ of normal goat $\mathrm{IgG}$ or $500 \mu \mathrm{g} /$ animal anti-MIP- $1 \beta$ neutralizing antibody $4 \mathrm{~h}$ before the first DNFB treatment. $* P<0.01$ for anti-MIP-1 $\beta$ vs. normal goat IgG.

sure. The administration of neutralizing anti-MIP-1 $\alpha$ or antiMIP-1 $\beta$ antibodies, either alone or in combination $4 \mathrm{~h}$ before DNFB application, had no significant effect on the DNFBinduced changes in mast cell densities either in skin or lymph nodes when assessed either 4 or $24 \mathrm{~h}$ after DNFB sensitization (data not shown).

Fluorescent-labeled mast cells migrate from skin to regional lymph nodes after DNFB sensitization. The parallel decrease in skin mast cell density and increase in lymph node mast cell numbers raised the possibility of mast cell migration from skin to lymph nodes via afferent lymphatics during DNFB sensitization. To investigate this possibility, BMMC were generated and labeled in vitro with one of two different fluorescent dyes, PKH-26 (red fluorescence) or PKH-2 (green fluorescence), then injected into left or right mouse footpads, respectively. These fluorescent dyes are permanently incorporated into cells even after cell division and thus reliably and irreversibly label the cells of interest. After $48 \mathrm{~h}$, the footpads were treated with DNFB on the left and acetone/olive oil on the right, and fluorescent-labeled mast cells were examined in the footpads and draining lymph nodes after the second exposure.

Similar numbers of fluorescent BMMCs were present in both the control (Fig. $4 \mathrm{~A}$ ) and DNFB-treated (Fig. $4 \mathrm{~B}$ ) footpads. There was only an occasional green fluorescent mast cell in the popliteal lymph nodes from the right leg (Fig. $4 C$ ), indicating minimal migration of intradermally injected labeled BMMCs from the footpad after exposure to acetone/olive oil only. In contrast, large numbers of red fluorescent BMMCs were observed in the subcapsular region of the popliteal lymph nodes from the left leg that had been exposed to DNFB (Fig. 4 $D$ ), providing direct evidence of migration of intradermally injected mast cells from skin to lymph nodes. There were no red fluorescent cells observed in the contralateral right popliteal lymph node, indicating migration was restricted to the affected

Figure 2 legend (Continued)

group)/mean percentage of degranulation in DNFB group]. Pretreatment of animals with anti-MIP-1 $\alpha$ antibody partially inhibits DNFB-induced mast cell degranulation, whereas pretreatment with normal goat IgG or anti-MIP-1 $\beta$ antibody did not cause significant inhibition of mast cell degranulation. No additional inhibition of degranulation was observed using a combination of anti-MIP-1 $\alpha$ plus anti-MIP-1 $\beta$, compared with anti-MIP-1 $\alpha$ alone. There are significant differences in inhibition of mast cell degranulation between anti-MIP-1 $\alpha$ antibody-treated mice and control normal goat IgG. Each experimental group consists of four animals. $* P<0.05$. 

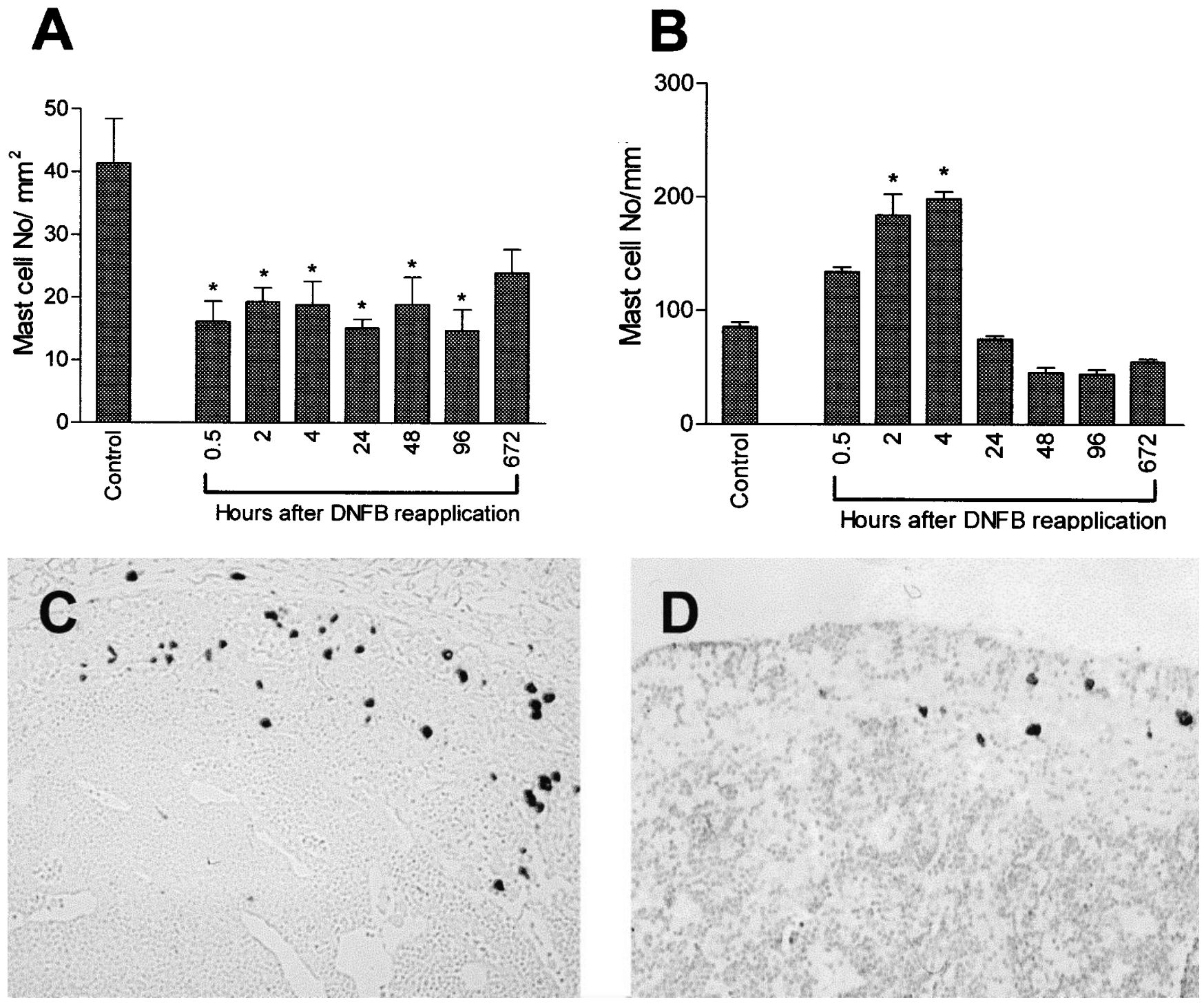

Figure 3. DNFB sensitization is associated with reciprocal changes in mast cell density (cells $\left./ \mathrm{mm}^{2}\right)$ in DNFB-exposed skin and draining inguinal lymph nodes. In skin $(A)$ significant differences in skin mast cell densities were found at $0.5-96 \mathrm{~h}$ after the second DNFB application, compared with the mast cell densities in control mice, treated with vehicle alone. Each point represents the mean \pm SEM from five animals. $* P<0.05$. In lymph nodes $(B)$ there was a rapid doubling of mast cell density, maximal $4 \mathrm{~h}$ after the second DNFB application compared with vehicle alone treated mice. ${ }^{*} P<0.01$. Each point represents the mean \pm SEM from three animals. $(C)$ Toluidine blue staining of an inguinal lymph node of a mouse taken $4 \mathrm{~h}$ after the second DNFB painting shows increased numbers of mast cells in the subcapsular region, compared with an inguinal lymph node taken from a control-treated animal $(D)$.

leg and that transit occurred by lymphatics, rather than via the systemic circulation.

Since the spleen has been reported to be a repository of effete mast cells during resolution of intestinal parasitic infec- tions (35), we examined this organ for fluorescent mast cells. Numerous red fluorescent mast cells were observed within the spleen $24 \mathrm{~h}$ after DNFB treatment to the left footpad (Fig. 4 $E$ ), suggesting migration from popliteal lymph nodes to the

Figure 4. Fluorescent-labeled mast cells injected into mouse footpads migrate to draining popliteal lymph nodes and spleen after DNFB application $(A-E)$. PKH-2 (green)-labeled BMMC or PKH-26 (red)-labeled BMMC are present in the right $(A)$ or left $(B)$ mouse footpads, respectively, when assessed $76 \mathrm{~h}$ after injection. Only an occasional green fluorescent mast cell is present in the right popliteal lymph node after two applications of acetone/olive oil vehicle control to the right footpad $(C)$. In contrast, many red fluorescent mast cells have migrated to the left popliteal lymph node when assessed $4 \mathrm{~h}$ after two DNFB applications to the left footpad $(D)$. Red fluorescent mast cells are also present in the spleen $24 \mathrm{~h}$ after two DNFB applications $(E)$. $(F-H)$ Lymph node mast cells produce MIP-1 $\beta$ mRNA after DNFB application to skin. In situ hybridization for expression of MIP-1 $\beta$ mRNA (blue color) in lymph node mast cells shows no expression of MIP-1 $1 \beta$ in lymph nodes from control-treated mice $(F)$ although mast cells are present (see Fig. $3 \mathrm{D}$ ), but there is abundant expression of this chemokine in subcapsular cells when assessed $4 \mathrm{~h}$ after two DNFB applications $(G)$. An adjacent section stained with anti-mMCP-5 antibody demonstrates that the MIP-1 $\beta$ mRNA-positive cells in the lymph nodes are mast cells $(H)$. 

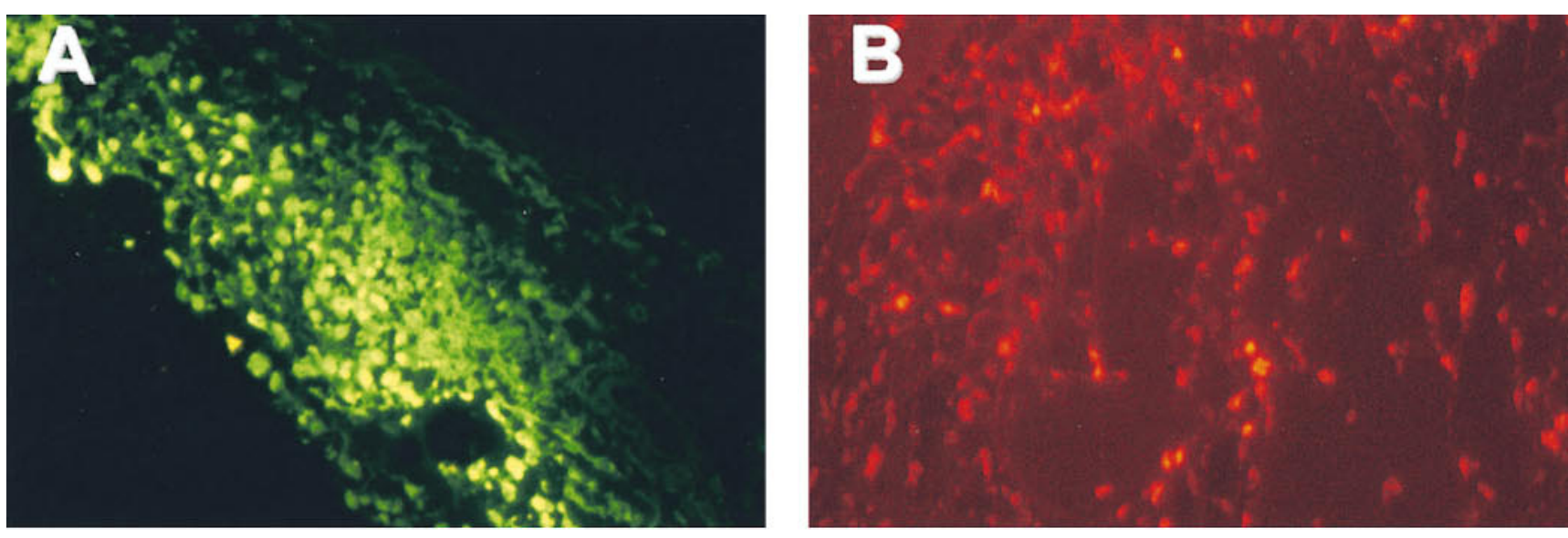

\section{C}

$y$
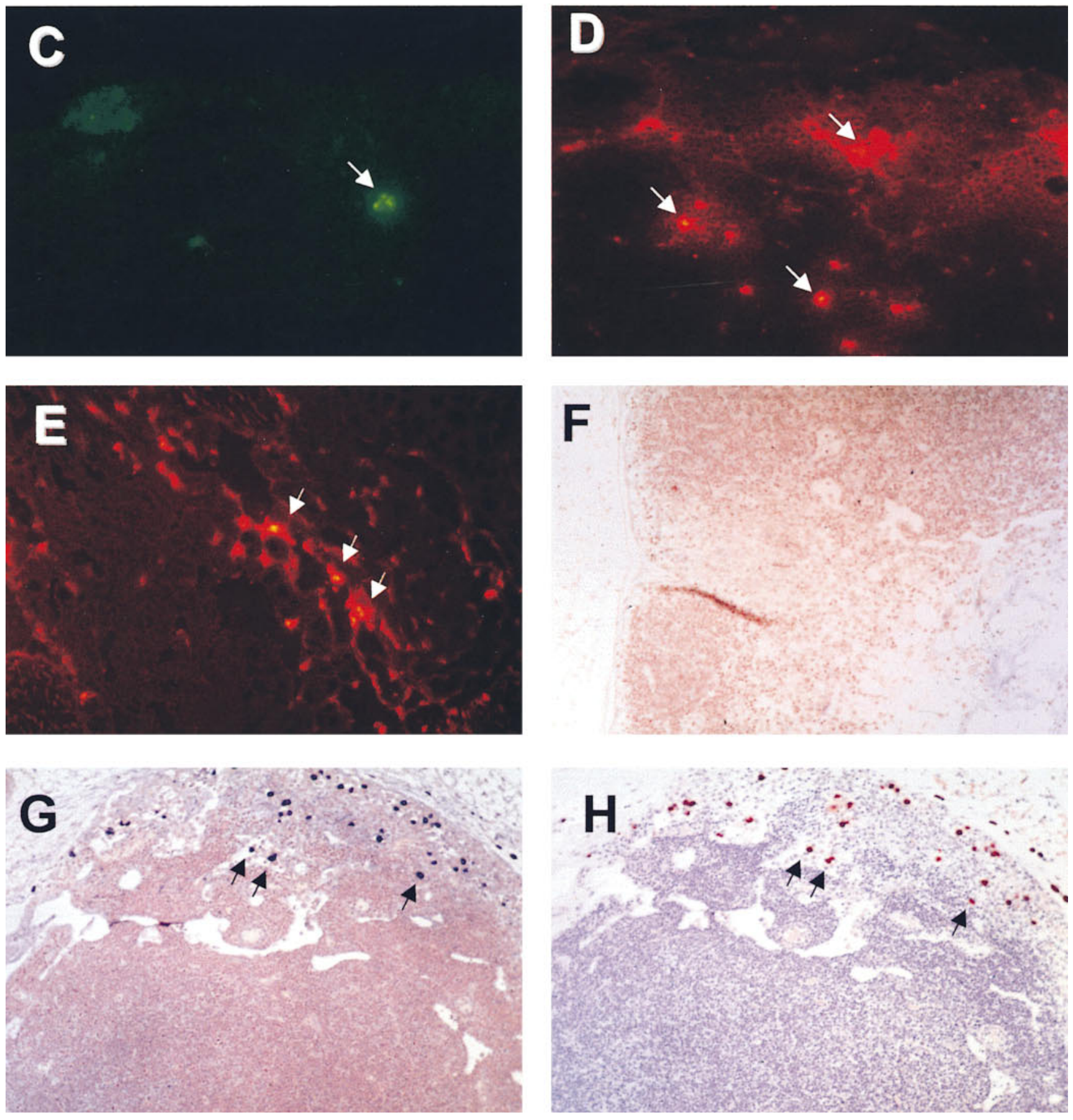
spleen. There were no green fluorescent mast cells observed in the spleen.

Lymph node mast cells produce MIP-1 $\beta$ which mediates $T$ lymphocyte recruitment to lymph nodes. As assessed by in situ hybridization, MIP-1 $\beta$ mRNA was absent in lymph nodes from control-treated mice (Fig. $4 F$ ), but it was abundantly induced after DNFB sensitization, predominantly by cells found in the subcapsular and hilar region (Fig. $4 G$ ). On adjacent sections, these cells were identified as mast cells by staining with either toluidine blue or anti-mMCP-5 antibody (Fig. $4 H$ ). The appearance of MIP-1 $\beta$ occurred in parallel with expansion of $\mathrm{T}$ lymphocytes in the lymph nodes, suggesting that this mast cell-derived chemokine was contributing to T lymphocyte recruitment. In support of this, the administration of neutralizing anti-MIP-1 $\beta$ antibodies $4 \mathrm{~h}$ before DNFB application caused an $\sim 50 \%$ inhibition of the T lymphocyte expansion compared with either untreated or control normal goat IgG-treated animals $(P<0.01)$ (Table I). The relationship between chemokine production and $\mathrm{T}$ lymphocyte recruitment in lymph nodes is described in more detail in reference 41.

\section{Discussion}

This study has described a number of novel observations concerning mast cells during the induction phase of a primary immune response, sensitization with the hapten DNFB. First, mast cell activation, which is partially due to local release of MIP- $1 \alpha$, is a major feature of the inflammatory response in the skin. Secondly, there is a $50 \%$ reduction of mast cell density in the sensitized skin concomitant with a fivefold expansion of mast cells in draining lymph nodes. This suggests migration of mast cells from skin to lymph nodes via afferent lymphatics and is supported by demonstration that fluorescent-labeled mast cells injected into the skin migrate to lymph nodes after DNFB application. Thirdly, mast cells were found to be the predominant source of MIP-1 $\beta$ in the draining lymph nodes, and neutralization of MIP- $1 \beta$ caused a $50 \%$ inhibition of $\mathrm{T}$ lymphocyte recruitment to lymph nodes, demonstrating the functional importance of this mast cell-derived chemokine during induction of this primary immune response.

Mast cell activation has been shown previously to be a prominent feature in the elicitation phase of contact hypersensitivity (42-45). The expression of various cytokines during both the sensitization and elicitation phases has been documented (46-49), including some that have specifically examined chemokine gene expression $(46,50,51)$, but the results have not been examined in relation to mast cell responses. In addition to a role in the elicitation phase, our results indicate that mast cell activation is also prominent in the sensitization phase of DNFB-induced hypersensitivity. Two striking observations were the degree of mast cell involvement with up to $77 \%$ of mast cells showing degranulation (Fig. $2 B$ ), and the prolonged nature of the degranulation (Fig. $2 E$ ). This suggests that the stimuli for mast cell activation are either extremely potent, that there are positive feedback mechanisms operating, or both. Several members of the $\beta$-chemokine family have been reported to activate basophils and eosinophils (52). There is less information for the effects of these molecules on mast cells, although MIP- $1 \alpha$ and MCP- 1 cause degranulation of mouse or rat (27-29) but not human mast cells (53).

The rapid induction of MIP- $1 \alpha$ mRNA and protein expression in keratinocytes observed after DNFB sensitization (Fig.
$1 B$ ) suggests that this chemokine could have initiated or augmented mast cell activation. The process by which DNFB application induces MIP- $1 \alpha$ production by keratinocytes has not been addressed in this study, but may involve the action of a proinflammatory cytokine such as TNF (54). After administration of neutralizing anti-MIP-1 $\alpha$ antibodies, mast cell degranulation was diminished qualitatively (Fig. $2 C$ ) and quantitatively (Fig. $2 F$ ) with $\sim 34 \%$ fewer mast cells being activated. This effect was specific for MIP- $1 \alpha$ since no significant inhibition of mast cell degranulation was observed after neutralization of MIP-1 $\beta$ (Fig. 2, $D$ and $F$ ). Since mast cells have been reported to produce MIP-1 $\alpha(14,15)$, it seems likely that local production of MIP- $1 \alpha$, initiated by keratinocytes and augmented by neutrophils and mast cells themselves, represents a powerful positive feedback cycle that is partially responsible for the prolonged mast cell degranulation observed. Additional mediators that may be contributing to mast cell activation are IP-10 and MCP-1, whose genes have been found to be induced in murine skin after application of hapten $(46,50,51)$.

A second major finding is the migration of skin mast cells to draining lymph nodes during DNFB sensitization. Application of DNFB to abdominal skin resulted in an $\sim 50 \%$ reduction in the density of local tissue mast cells (Fig. $3 A$ ). This reduction is not explicable by a failure to visualize completely degranulated mast cells that were not stained with toluidine blue, as even extensively degranulated mast cells were clearly visible as clumps of residual granules (Fig. 2 B). In parallel with the loss of skin mast cells, there was a rapid increase in the mast cell density in the draining lymph nodes (Fig. 3, $B$ and $C)$. The rapid kinetics and selective expansion in the subcapsular region of the lymph nodes are most readily explained by the arrival of mast cells via afferent lymphatics rather than by local proliferation. Rapid increases in lung mast cell numbers in dogs (33) and human asthmatics (34) after antigen exposure provide support for our data and the notion of mast cell movement within tissues.

To confirm that skin mast cells migrate to draining lymph nodes, we fluorescent-labeled cultured mast cells and tracked them after injection into the footpads of mice. Numerous fluorescent mast cells remained within the footpad skin when assessed $76 \mathrm{~h}$ after injection (Fig. 4, $A$ and $B$ ). Treatment of the footpad with DNFB resulted in migration of (red) fluorescent cells to the draining popliteal lymph node (Fig. $4 \mathrm{D}$ ), but not to lymph nodes on the contralateral node (Fig. $4 \mathrm{C}$ ), indicating migration via afferent lymphatics rather than via the vasculature. There was minimal migration of (green) labeled cells from the vehicle control-treated footpad to lymph nodes on either side. These results are the first direct in vivo evidence that mast cells migrate via afferent lymphatics to draining lymph nodes. Furthermore, the appearance of fluorescent mast cells in the spleen (Fig. $4 E$ ) is consistent with subsequent migration from lymph nodes to the blood stream, presumably via efferent lymphatics, and is supported by a recent study showing that jejunal mast cells migrate to the spleen during resolution of intestinal parasitic infection (35).

The mechanisms responsible for mast cell migration are poorly understood. Of the various molecules studied, the chemokines, MCP-1, RANTES, PF4, and MIP-1 $\alpha$ (30), the complement proteins, $\mathrm{C} 1 \mathrm{q}, \mathrm{C} 3 \mathrm{a}$, and $\mathrm{C} 5 \mathrm{a}(55,56)$, the angiogenic factors, PDGF, VEGF, and bFGF (57), and the cytokines, IL-3 (58), TGF- $\beta$ (59), and stem cell factor (60) have been reported to be chemotactic for mast cells in vitro. Activa- 
tion of cutaneous dendritic cells by TNF has been associated with their migration to lymph nodes (61). In this study, mast cells appearing in lymph nodes after DNFB exhibited no evidence of degranulation as assessed by toluidine blue staining, suggesting that the stimuli for degranulation and migration of mast cells are distinct. Indeed, it is unlikely that MIP- $1 \alpha$ was responsible for mediating mast cell migration to lymph nodes, since it was more abundantly expressed in the skin than lymph nodes (41), creating a gradient that would favor retention of mast cells in the skin. In addition, neutralization of MIP- $1 \alpha$ had no effect on either the decrease of mast cell numbers in the skin or the increase in lymph nodes during DNFB sensitization.

It is well-established that epidermal Langerhans cells take up antigen in the skin and move into regional lymph nodes via afferent lymphatics (62), wherein they present antigen to $\mathrm{T}$ lymphocytes. The observations in this study that dermal mast cells follow the same course raise the possibility that mast cells may also be transporting antigen in this fashion. Several studies have provided evidence that mast cells can act as antigenpresenting cells in vitro $(17,19)$, a function that is augmented by cytokines such as GM-CSF and IL-4 and abrogated by IFN- $\gamma$ (18).

Whereas mouse and human mast cells have been shown to express various chemokine genes in vitro (14-16), this study is the first demonstration of expression of MIP- $1 \beta$ by mast cells in vivo in the setting of an inflammatory response (Fig. 1, $E$ and $F$, and Fig. 4, $G$ and $H$ ). Although this expression was relatively limited in the skin, in comparison to keratinocytes and fibroblasts, mast cells were an abundant and predominant source of MIP-1 $\beta$ in the draining lymph nodes during DNFB sensitization. Since human MIP-1 $\beta$ is chemotactic for T lymphocytes $(63,64)$, the migration of mast cells from the skin to lymph nodes and their production of MIP-1 $\beta$ may be an important mechanism to facilitate $\mathrm{T}$ lymphocyte recruitment to lymph nodes. In support of this, inhibition of mast cell-derived MIP- $1 \beta$ using neutralizing antibody resulted in $\sim 50 \%$ inhibition in the recruitment of T lymphocytes to lymph nodes during DNFB sensitization (Table I).

The immunological processes we have observed in this study allow us to hypothesize a sequence of events occurring in the sensitization phase of DNFB-induced contact sensitivity. Antigen encounter elicits, among other events, a rapid induction of MIP- $1 \alpha$ production by keratinocytes, one result of which is local mast cell activation. Release of a range of mediators by mast cells causes acute inflammation, including neutrophil recruitment. MIP- $1 \alpha$ production by neutrophils, fibroblasts, and mast cells themselves augments and prolongs mast cell degranulation resulting in a positive feedback system. At the same time, mast cells traffic to the draining lymph nodes and produce MIP- $1 \beta$. In lymph nodes, mast cells are the primary source of this chemokine that participates in T lymphocyte recruitment to facilitate antigen presentation and the initiation of an adaptive immune response.

\section{Acknowledgments}

We thank Dr. Manju Verma for her assistance in the preparation of MIP- $1 \alpha$ and MIP- $1 \beta$ probes.

This work was supported by grants from the Arthritis Foundation of Australia and the National Health and Medical Research Council of Australia.

\section{References}

1. McNeil, H.P. 1996. The mast cell and inflammation. Aust. N. Z. J. Med. 26:216-225.

2. Gaboury, J.P., B. Johnston, X.F. Niu, and P. Kubes. 1995. Mechanisms underlying acute mast cell-induced leukocyte rolling and adhesion in vivo. J. Immunol. 154:804-813.

3. Kubes, P., and S. Kanwar. 1994. Histamine induces leukocyte rolling in post-capillary venules. A P-selectin-mediated event. J. Immunol. 152:35703577.

4. Wershil, B.K., G.T. Furuta, Z.S. Wang, and S.J. Galli. 1996. Mast celldependent neutrophil and mononuclear cell recruitment in immunoglobulin E-induced gastric reactions in mice. Gastroenterology. 110:1482-1490.

5. Walsh, L.J., G. Trinchieri, H.A. Waldorf, D. Whitaker, and G.F. Murphy. 1991. Human dermal mast cells contain and release tumor necrosis factor $\alpha$, which induces endothelial leukocyte adhesion molecule 1. Proc. Natl. Acad. Sci. USA. 88:4220-4224.

6. Malaviya, R., E.A. Ross, J.I. MacGregor, T. Ikeda, J.R. Little, B.A. Jakschik, and S.N. Abraham. 1994. Mast cell phagocytosis of FimH-expressing enterobacteria. J. Immunol. 152:1907-1914.

7. Malaviya, R., T. Ikeda, E. Ross, and S.N. Abraham. 1996. Mast cell modulation of neutrophil influx and bacterial clearance at sites of infection through TNF- $\alpha$. Nature. 381:77-80.

8. Echtenacher, B., D.N. Mannel, and L. Hultner. 1996. Critical protective role of mast cells in a model of acute septic peritonitis. Nature. 381:75-77.

9. Gauchat, J.F., S. Henchoz, G. Mazzei, J.P. Aubry, T. Brunner, H. Blasey, P. Life, D. Talabot, L. Flores-Romo, J. Thompson, et al. 1993. Induction of human IgE synthesis in B cells by mast cells and basophils. Nature. 365:340-343.

10. Mecheri, S., and B. David. 1997. Unravelling the mast cell dilemma: culprit or victim of its generosity? Immunol. Today. 18:212-215.

11. Liu, F.T. 1997. Truly MASTerful cells: mast cells command B cell IgE synthesis. J. Clin. Invest. 99:1465-1466.

12. Williams, C.M., and J.W. Coleman. 1995. Induced expression of mRNA for IL-5, IL-6, TNF- $\alpha$, MIP-2 and IFN- $\gamma$ in immunologically activated rat peritoneal mast cells: inhibition by dexamethasone and cyclosporin A. Immunology. 86:244-249.

13. Gordon, J.R., and S.J. Galli. 1990. Mast cells as a source of both preformed and immunologically inducible TNF- $\alpha$ /cachectin. Nature. 346:274-276.

14. Burd, P.R., H.W. Rogers, J.R. Gordon, C.A. Martin, S. Jayaraman, S.D. Wilson, A.M. Dvorak, S.J. Galli, and M.E. Dorf. 1989. Interleukin 3-dependent and -independent mast cells stimulated with $\operatorname{IgE}$ and antigen express multiple cytokines. J. Exp. Med. 170:245-257.

15. Yano K., M. Yamguchi, F. deMora, C.S. Lantz, J.H. Butterfield, J.J. Costa, and S.J. Galli. 1997. Production of macrophage inflammatory protein-1 $\alpha$ by human mast cells: increased anti-IgE-dependent secretion after IgE-dependent enhancement of mast cell IgE-binding ability. Lab. Invest. 77:185-193.

16. Moller, A., U. Lippert, D. Lessmann, G. Kolde, K. Hamann, P. Welker, D. Schadendorf, T. Rosenbach, T. Luger, and B.M. Czarnetzki. 1993. Human mast cells produce IL-8. J. Immunol. 151:3261-3266.

17. Fox, C.C., S.D. Jewell, and C.C. Whitacre. 1994. Rat peritoneal mast cells present antigen to a PPD-specific T cell line. Cell. Immunol. 158:253-264.

18. Frandji, P., C. Tkaczyk, C. Oskeritzian, J. Lapeyre, R. Peronet, B. David, J.G. Guillet, and S. Mecheri. 1995. Presentation of soluble antigens by mast cells: upregulation by interleukin-4 and granulocyte/macrophage colonystimulating factor and downregulation by interferon- $\gamma$. Cell. Immunol. 163:3746.

19. Frandji, P., C. Oskeritzian, F. Cacaraci, J. Lapeyre, R. Peronet, B David, J.G. Guillet, and S. Mecheri. 1993. Antigen-dependent stimulation by bone marrow-derived mast cells of MHC class II-restricted T cell hybridoma. $J$. Immunol. 151:6318-6328.

20. Alber, G., U.M. Kent, and H. Metzger. 1992. Functional comparison of FceRI, Fc $\gamma$ RII, and Fc $\gamma$ RIII in mast cells. J. Immunol. 149:2428-2436.

21. Katz, H.R., M.B. Raizman, C.S. Gartner, H.C. Scott, A.C. Benson, and K.F. Austen. 1992. Secretory granule mediator release and generation of oxidative metabolites of arachidonic acid via $\mathrm{Fc}-\mathrm{IgG}$ receptor bridging in mouse mast cells. J. Immunol. 148:868-871.

22. Sylvestre, D.L., and J.V. Ravetch. 1994. Fc receptors initiate the Arthus reaction: redefining the inflammatory cascade. Science. 265:1095-1098.

23. Ramos, B.F., Y. Zhang, and B.A. Jakschik. 1994. Neutrophil elicitation in the reverse passive Arthus reaction. Complement-dependent and -independent mast cell involvement. J. Immunol. 152:1380-1384.

24. Columbo, M., E.M. Horowitz, A. Kagey-Sobotka, and L.M. Lichtenstein. 1996. Substance P activates the release of histamine from human skin mast cells through a pertussis toxin-sensitive and protein kinase C-dependent mechanism. Clin. Immunol. Immunopathol. 81:68-73.

25. Niizeki, H., P. Alard, and J.W. Streilein. 1997. Calcitonin gene-related peptide is necessary for ultraviolet B-impaired induction of contact hypersensitivity. J. Immunol. 159:5183-5186.

26. Yamamura, H., T. Nabe, S. Kohno, and K. Ohata. 1994. Endothelin-1 induces release of histamine and leukotriene $\mathrm{C}_{4}$ from mouse bone marrowderived mast cells. Eur. J. Pharmacol. 257:235-242.

27. Alam, R., P.A. Forsythe, S. Stafford, M.A. Lett-Brown, and J.A. Grant. 
1992. Macrophage inflammatory protein- $1 \alpha$ activates basophils and mast cells. J. Exp. Med. 176:781-786.

28. Conti, P., W. Boucher, R. Letourneau, C. Feliciani, M. Reale, R.C. Barbacane, P. Vlagopoulos, G. Bruneau, J. Thibault, and T.C. Theoharides. 1995. Monocyte chemotactic protein-1 provokes mast cell aggregation and $\left[{ }^{3} \mathrm{H}\right] 5 \mathrm{HT}$ release. Immunology. 86:434-440.

29. Alam, R., D. Kumar, D. Anderson-Walters, and P.A. Forsythe. 1994. Macrophage inflammatory protein- $1 \alpha$ and monocyte chemoattractant peptide- 1 elicit immediate and late cutaneous reactions and activate murine mast cells in vivo. J. Immunol. 152:1298-1303.

30. Taub, D., J. Dastych, N. Inamura, J. Upton, D. Kelvin, D. Metcalfe, and J. Oppenheim. 1995. Bone marrow-derived murine mast cells migrate, but do not degranulate, in response to chemokines. J. Immunol. 154:2393-2402.

31. Koshino, T., Y. Arai, Y. Miyamoto, Y. Sano, M. Itami, S. Teshima, K. Hirai, T. Takaishi, K. Ito, and Y. Morita. 1996. Airway basophil and mast cell density in patients with bronchial asthma: relationship to bronchial hyperresponsiveness. J. Asthma. 33:89-95.

32. Gotis-Graham, I., and H.P. McNeil. 1997. Mast cell responses in rheumatoid synovium. Association of the $\mathrm{MC}_{\mathrm{TC}}$ subset with matrix turnover and clinical progression. Arthritis Rheum. 40:479-489.

33. Turner, C.R., J. Kolbe, and E.W. Spannhake. 1988. Rapid increase in mast cell numbers in canine central and peripheral airways. J. Appl. Physiol. 65: 445-451.

34. Montefort, S., C. Gratziou, D. Goulding, R. Polosa, D.O. Haskard, P.H. Howarth, S.T. Holgate, and M.P. Carroll. 1994. Bronchial biopsy evidence for leukocyte infiltration and upregulation of leukocyte-endothelial cell adhesion molecules 6 hours after local allergen challenge of sensitized asthmatic airways. J. Clin. Invest. 93:1411-1421.

35. Friend, D.S., M.F. Gurish, J. Hunt, X. Hu, K.F. Austen, and R.L. Stevens. 1998. Fate of jejunal mast cells in mice infected with Trichinella spiralis. FASEB (Fed. Am. Soc. Exp. Biol.) J. 12:A894.

36. Kurimoto, I., and J.W. Streilein. 1993. Studies of contact hypersensitivity induction in mice with optimal sensitizing doses of hapten. J. Invest. Dermatol. 101:132-136.

37. Stead, R.H., A.J. Franks, C.H. Goldsmith, J. Bienenstock, and M.F. Dixon. 1990. Mast cells, nerves and fibrosis in the appendix: a morphological assessment. J. Pathol. 161:209-219.

38. Halasz, P., and P. Martin. 1984. Microcomputer based system for semiautomatic analysis of histological sections. Proc. Royal Microscop. Soc. 19:312318

39. Walker, M., R. Harley, J. Maize, F. DeLustro, and E.C. LeRoy. 1985. Mast cells and their degranulation in the Tsk mouse model of scleroderma. Proc. Soc. Exp. Biol. Med. 180:323-328.

40. McNeil, H.P., D.P. Frenkel, K.F. Austen, D.S. Friend, and R.L. Stevens. 1992. Translation and granule localization of mouse mast cell protease-5. Immunodetection with specific antipeptide Ig. J. Immunol. 149:2466-2472.

41. Tedla, N., H.W. Wang, H.P. McNeil, N. diGirolamo, T. Hampartzoumian, D. Wakefield, and A. Lloyd. 1998. Regulation of T lymphocyte trafficking into lymph nodes during an immune response by the chemokines, MIP$1 \alpha$ and MIP-1 $1 \beta$. J. Immunol. In press.

42. Kupper, T.S. 1995. Immunity and inflammation in cutaneous tissues. In Samter's Immunologic Diseases. Vol. 1. M.M. Frank, K.F. Austen, H.N. Claman, and E.R. Unanue, editors. Little, Brown and Company, Boston. 353-362.

43. Askenase, P.W., H. Van Loveren, S. Kraeuter-Kops, Y. Ron, R. Meade, T.C. Theoharides, J.J. Nordlund, H. Scovern, M.D. Gerhson, and W. Ptak. 1983. Defective elicitation of delayed-type hypersensitivity in W/Wv and SI/SId mast cell-deficient mice. J. Immunol. 131:2687-2694.

44. Matsuda, H., H. Ushio, V. Paliwal, W. Ptak, and P.W. Askenase. 1995. Adoptive cell transfer of contact sensitivity-initiation mediated by nonimmune cells sensitized with monoclonal IgE antibodies. Dependence on host skin mast cells. J. Immunol. 154:5080-5092.

45. Geba, G.P., W. Ptak, G.M. Anderson, V. Paliwal, R.E. Ratzlaff, J.
Levin, and P.W. Askenase. 1996. Delayed-type hypersensitivity in mast celldeficient mice: dependence on platelets for expression of contact sensitivity. $J$. Immunol. 157:557-565.

46. Enk, A.H., and S.I. Katz. 1992. Early molecular events in the induction phase of contact sensitivity. Proc. Natl. Acad. Sci. USA. 89:1398-1402.

47. Enk, A.H., V.L. Angeloni, M.C. Udey, and S.I. Katz. 1993. An essential role for Langerhans cell-derived IL- $1 \beta$ in the initiation of primary immune responses in skin. J. Immunol. 150:3698-3704.

48. Kondo, S., S. Pastore, G.M. Shivji, R.C. McKenzie, and D.N. Sauder. 1994. Characterization of epidermal cytokine profiles in sensitization and elicitation phases of allergic contact dermatitis as well as irritant contact dermatitis in mouse skin. Lymphokine Cytokine Res. 13:367-375.

49. Asada, H., J. Linton, and S.I. Katz. 1997. Cytokine gene expression during the elicitation phase of contact sensitivity: regulation by endogenous IL-4. $J$. Invest. Dermatol. 108:406-411.

50. Gautam, S., J. Battisto, J.A. Major, D. Armstrong, M. Stoler, and T.A. Hamilton. 1994. Chemokine expression in trinitrochlorobenzene-mediated contact hypersensitivity. J. Leukocyte Biol. 55:452-460.

51. Abe, M., T. Kondo, H. Xu, and R.L. Fairchild. 1996. Interferon- $\gamma$ inducible protein (IP-10) expression is mediated by CD8+ T cells and is regulated by CD4+ T cells during the elicitation of contact hypersensitivity. J. Invest. Dermatol. 107:360-366.

52. Kaplan, A.P., P. Kuna, and S.R. Reddigari. 1995. Chemokines and the allergic response. Exp. Dermatol. 4:260-265.

53. Petersen, L.J., K. Brasso, M. Pryds, and P.S. Skov. 1996. Histamine release in intact human skin by monocyte chemoattractant factor-1, RANTES macrophage inflammatory protein- $1 \alpha$, stem cell factor, anti-IgE, and codeine as determined by an ex vivo skin microdialysis technique. J. Allergy Clin. Immunol. 98:790-796.

54. Li, J., G.W. Ireland, P.M. Farthing, and M.H. Thornbill. 1996. Epidermal and oral keratinocytes are induced to produce RANTES and IL-8 by cytokine stimulation. J. Invest. Dermatol. 106:661-666.

55. Ghebrehiwet, B., R.R. Kew, B.L. Gruber, M.J. Marchese, E.I. Peerschke, and K.B. Reid. 1995. Murine mast cells express two types of C1q receptors that are involved in the induction of chemotaxis and chemokinesis. J. Immunol. 155:2614-2619.

56. Nilsson, G., M. Johnell, C.H. Hammer, H.L. Tiffany, K. Nilsson, D.D Metcalfe, A. Siegbahn, and P.M. Murphy. 1996. C3a and C5a are chemotaxins for human mast cells and act through distinct receptors via a pertussis toxin sensitive signal transduction pathway. J. Immunol. 157:1693-1698.

57. Gruber, B.L., M.J. Marchese, and R. Kew. 1995. Angiogenic factors stimulate mast-cell migration. Blood. 86:2488-2493.

58. Matsuura, N., and B.R. Zetter. 1989. Stimulation of mast cell chemotaxis by interleukin 3. J. Exp. Med. 170:1421-1426.

59. Gruber, B.L., M.J. Marchese, and R.R. Kew. 1994. Transforming growth factor- $\beta 1$ mediates mast cell chemotaxis. J. Immunol. 152:5860-5867.

60. Nilsson, G., J.H. Butterfield, K. Nilsson, and A. Siegbahn. 1994. Stem cell factor is a chemotactic factor for human mast cells. J. Immunol. 153:37173723

61. Cumberbatch, M., and I. Kimber. 1992. Dermal tumour necrosis factor- $\alpha$ induces dendritic cell migration to draining lymph nodes, and possibly provides one stimulus for Langerhans cell migration. Immunology. 75:257-263.

62. Kripke, M.L., C.G. Munn, A. Jeevan, J.M. Tang, and C. Bucana. 1990. Evidence that cutaneous antigen-presenting cells migrate to regional lymph nodes during contact sensitization. J. Immunol. 145:2833-2838.

63. Schall, T.J., K. Bacon, R.D. Camp, J.W. Kaspari, and D.V. Goeddel. 1993. Human macrophage inflammatory protein $\alpha$ (MIP-1 $\alpha$ ) and MIP-1 $\beta$ chemokines attract distinct populations of lymphocytes. J. Exp. Med. 177:18211826.

64. Taub, D.D., K. Conlon, A.R. Lloyd, J.J. Oppenheim, and D.J. Kelvin. 1993. Preferential migration of activated CD4+ and CD8+ T cells in response to MIP-1 $\alpha$ and MIP-1 $\beta$. Science. 260:355-358. 